\title{
Research on Marriage View in Alice Munro's Novels
}

\author{
Hui Gao \\ Xi’an Fanyi University, Shaanxi, Xi'an, 710105
}

Keywords: Selflessness, Respect, Tolerance, Equality

\begin{abstract}
In Alice Munro's work, marriage is a more common subject, especially for marital violence and support for feminism, and is the main problem that Alice Munro will describe. The concept of marriage of Alice Munro is reflected in many works by Alice Munro, in general, in the sense of selflessness and responsibility, self-esteem and respect, tolerance and forgiveness and search for equality of men and women.
\end{abstract}

\section{Introduction}

Canadian woman writer Alice Munro stands out to win the Nobel Prize for Literature in 2013, for herself, and for the Canadian literature. Prior to that, Munro won the Governor General's Literary Award for English language fiction in 1968, 1978 and 1986. And in 2006 and 2008, Alice Munro won O• Henry Award for continuing achievement in short fiction in the U•S. And in 2009 she was awarded the Man Booker International Prize. It can be said that Alice Munro has made such a great achievement, mainly because of its articles' delicate and unique interpretation of women and marriage. The works of Alice Munro is the process of female self-innovation and self-salvation after her experience of violence and suffering, constantly in the pain to actively find the meaning of self and life, not only reveals the deep pursuit of woman's deep connotation, but also let the reader understand the author's mind, that is, what kind of marriage in her mind. Through the novel, she constantly tells the world, as a want to grasp their own fate, women should control their own life and marriage. Therefore, Alice Munro's works are mostly infected with women to forge ahead and healing the effect of female pain. Through the works of Alice Munro, whether it is "The Progress of Love" or "Runaway" which won the Nobel Prize and so on to the reader to explain Alice Munro's own marriage concept. So, in this article the author mainly explains Alice Munro's marriage concept, specifically, Alice Munro’s concept of marriage mainly involves a few main points as follows.

\section{Selflessness and Responsibility}

In Alice Munro's heart, the real love is selfless, selfless to the happiness of each other and love will be buried in the heart. Alice Munro does not think that love must be spent, and marriage is not necessarily a simple love at first sight, but with the passage of time, gradually derived from the emotions. And for marriage, in addition to love, it needs for a sense of responsibility as a basis. For example, in Alice Munro's short story "Nettles", it is about a divorced woman met child-hood sweetheart, old lover Mike. Because they were accidentally mistaken when they were young, the two finally did not come together, each with their own family. But when the heroine "I" divorced, once again met Mike, "I" and Mike wanted to continue to lead the front. But when "I" listened to Mike about the child's sickness, Mike and his wife were trying to cure the child, which let "I" understand that Mike and his wife's love is indestructible, also "I" aware that the love between male and female does not have to stay together, but we should put each other in their own hearts, quietly wish each other well. "Nettles" can be counted as the typical work that Alice Munro explains her view of marriage and love. In this work, Mike and the heroine "I" are in love with each other, but this love is only psychological and not to rise to the height of the struggle and experience. It is simply said that their love is not to talk about the sense of responsibility. But marriage is different, marriage is to be happy for each other, to give up their own single happiness, together to meet 
suffering, whereas love is the need to have a strong sense of responsibility as a support. Because Mike took care of children and his wife's responsibility, so to face the reality of the child's sickness, the whole family face the suffering together. In this suffering, Mike and his wife's love gradually sublimated, from simple to the last to become the love between each other that they really cannot leave. In addition, the marriage is still selfless, in the "Nettles", it is not difficult to see that the feelings between Mike and the heroine "I" are real, they love each other but destined not to be together, because of Mike's marriage. To Mike, he chose to sacrifice personal feelings, and willing to hang around in the marriage. And as a divorced "I", in order to help Mike to pursue his own happiness and respect for the marriage, "I" can only hide my love in the heart, and quietly wish each other good.

\section{Self-esteem and Be Respected}

Alice Munro's works are mostly from the female perspective, describing the marriage and growth of woman's experience, it can be said that Alice Munro is very concerned about women and her works are the representative of feminist novels. Therefore, based on the female perspective, Alice Munro believes that as a woman, she should be full of self-esteem and also be respected by men in marriage. This view is reflected in most of the works of Alice Munro, for example, in the novel "The progress of love", the main story is about the different ideas for marriage and self in the three generations of women in different times. The first generation of women "grandmother" in the marriage is without her true self, she believes that women are dependent on men, when the men ignore them, it is necessary to find ways to arouse the attention of men and regain favor. The second-generation women are "mother" and Aunt Rebel, "my" mother has a certain sense of her self, she longs to get the respect of men and wants to be an autonomous and independent personality of the individual. But, "my" mother is relatively more tolerant, and she tries hard to do her own, but there is no any substantive change to the attached fate to people. Aunt Rebel is more like "my" grandmother, she likes to dress up, and eager to get man's attention through the appearance. The third generation of women "I" is more like "mother", but more brave than the "mother". "I" desire to make changes for my own destiny and the fate of women around the world through my own efforts in the marriage, "I" am eager to control my own marriage and have my own independent economic sources which could give myself the respect. In this novel, it is not difficult to find through the lines that Alice Munro supports the attitude of "I", which shows that in the marriage concept, the author holds that women should have self-esteem, only having self-esteem and a certain source of income can woman become an independent individual, only their desire to dominate their own destiny can really let men respect them. At the same time, the author also believes that in marriage women should deserve respect, the same respect for woman as a male, not simply to women as a male's attachment, this is the only way to the normal marriage.

\section{Tolerance and Forgiveness}

Alice Munro has repeatedly emphasized the importance of tolerance and forgiveness in her novels. Many of Alice Munro's stories are based on the Huron County in Ontario, which is very contemporary and appeared in Alice Munro's times. Most of them are more serious thinking of male rights, in order to fight for their sovereignty women need to pay a lot of efforts in this time. Therefore, as the women of this period, to fight for sovereignty only in the marriage is not enough, they also need to have tolerance and forgiveness for the current era, especially to tolerate serious thinking of male rights of this era, at the same time also forgive arrogance and conceit of the men in this period. In "The Progress of Love", there has such a sentence, "Hatred is always a sin, mother told me, remember this. A drop of hatred in your soul will spread to destroy all the colors, just like a drop of black ink in the white milk . I was shocked by this remark and quite want to have a test, but I know I cannot waste milk." This sentence has great impact on "I" in the story, but also can be said to be Alice Munro's portrayal of the concept of marriage. It is hard for independent and respectable women in this particular period to have no hatred, but the author thinks that in order to allow 
women to escape from the torture of the hatred in marriage, only with forgiveness and tolerance to comfort themselves, and through using tolerance and forgiveness to infect each other to fight for their own rights at the same time. This view also explained in Alice Munro's novels for male domestic violence. For example, the short stories "Fathers", recent works "Runaway" and "Trespasses" described male domestic violence. These novels are not simply suing how fierce and lack of human nature of the men in the interpretation of domestic violence, but in the search for the problems behind violence. These novels have all-round analysis of the traditional male temperament statute under the characteristics of the perpetrators, but also very tolerant to find out generated psychological reasons of the male family violence. Because their social class is lower, they bear greater economic pressure. In social interaction, they despise social rules and not easy to get along with the people around, so they are prone to low self-esteem and closed psychology. In the novel, Alice Munro tells that women should tolerate but not condone, forgive but not compromise, it can be said that this is also Alice Munro's view of marriage. During the tolerance and understanding of each other, try to get common happiness for two people in the marriage.

\section{The Idea of Equality between Men and Women}

In the works of Alice Munro, she never forgets the fight for woman's rights. During Alice Munro's life, male's thought is still more serious, domestic violence is everywhere, which gives the heart of Alice Munro the indelible damage. But this also promotes Alice Munro to the formation of the concept of equality between men and women through writing with the male thought and domestic violence to fight for. This idea of equality is also reflected in Alice Munro's view of marriage, for example, in "The Progress of Love", the protagonist "I" has been fighting for her own rights, when her husband and father do not respect "my" thinking, "I" will be very angry and even make counterattack. It can be said that this is the budding idea of equality between men and women in "my" heart. Like this example, the author gives some clear examples of the image, so that readers feel the existence of inequality in domestic violence and marital relations, in order to call for the fight against this inequality. For example, in "Runaway", the husband always scolded his wife , he said that his wife is useless, in order to demonstrate his rights at the same time strangled his wife's personality. In "Trespasses", the husband always asked his wife to breastfeed his son, and his wife did all the housework, which shows their status. In addition, "Fathers" reflects the male violence against women everywhere, thoughtful enough to make women wake up, and thus have the courage to fight for their own rights. In Alice Munro's works, whether it is to describe those women who dare to show personality and self-esteem without being afraid of male, or the description of some male and female inequality, all can be counted as the right to fight for women. Like those women who are in the blood history of violent marriage and those who want to fight for their rights in the marriage, the marriage can show respect for the women, to retain the spirit of woman's independence and so on. All these are the embodiment of equality in Alice Munro's works.

In summary, the author analyzed Alice Munro's marriage concept combined with Alice Munro's works. Alice Munro, who has published 14 works, including 13 short stories and a similar story collection of novels so far, mostly regards women as the center, focusing on the ordinary town of Canada's life experience, to explore the ordinary woman's complex psychological and emotional state. In a calm and delicate narrative, in order to bring reading and soul tremor to the reader, many of these novels are full of the author's view of the marriage. It can be said that anything is not achieved overnight, especially women fight for their own rights, it is even more difficult for them. In Alice Munro's works, the interpretation of the concept of marriage is related to the environment and experience of her own growth, and it is also related to the value of the status of women. From this perspective, Alice Munro is not only a writer, but also a feminist. Alice Munro is always talking about woman's rights for women in marriage, women must have self-esteem and tolerance. The sense of marriage in Alice Munro is based on equality, and the status of equality is increasing in marriage. It is necessary to increase the status of equality in marriage and everyone needs to fight for it. 


\section{Acknowledgements}

Fund Project: Shaanxi Provincial Department of Education 2016 Annual Scientific Research Project Xi’an Fanyi University Special Project, project number: 16JK2059.

\section{References}

[1] Jiang Xin, Shi Guiren. Alice Munro's eco-female writing[J]. Contemporary writer comments .2014 (2)

[2] Xiao Ling, Chen Tanglong. Alice Munro and Margaret Atwood's ecological feminism comparative study[J]. Learning and exploration .2014 (12)

[3] Days line. Alice Munro and its creation brief. [J]. Reading book .2014 (2)

[4] Wang Yan. Alice Munro’s novels in the occurrence and evolution of female consciousness[J]. Social Sciences Journal .2015 (1)

[5] Wang Yicheng. The reason for the escape - analysis of Alice Munro's "Runaway"[J]. Global Human Geography .2014 (10) 